\title{
Pyridinium chlorides equipped with long chains as amphiphiles for potential nonviral gene delivery ${ }^{\S}$
}

\author{
Mariana Viorica Bogatian, ${ }^{\text {a* }}$ Valentin Cimpeanu, ${ }^{a}$ Călin Deleanu,,${ }^{\text {a,d }}$ \\ Andreea Cristina Corbu, ${ }^{\text {a,d }}$ Gheorghe Bogatian, ${ }^{b}$ and Teodor Silviu Balaban ${ }^{c^{*}}$ \\ ${ }^{a}$ Costin D. Nenitzescu Institute of Organic Chemistry, Romanian Academy, \\ Splaiul Independentei, 202B, 71141, P.O. Box 108, Bucharest 35, Romania \\ ${ }^{b}$ Vigra Marketing \& Services s.r.l., Str. Grațioasă 6, Bucharest, Romania \\ ${ }^{c}$ Forschungszentrum Karlsruhe, Institut für Nanotechnologie, Postfach 3640, \\ D-76021 Karlsruhe, Germany \\ ${ }^{d}$ National NMR Laboratory, P. O. Box 35-98 Bucharest, Romania \\ E-mail: mbogat@,cco.ro or silviu.balaban@int.fzk.de
}

\section{Dedicated to Prof. Dr. Alexandru T. Balaban on the occasion of his $75^{\text {th }}$ birthday}

(received 29 Jun 05; accepted 20 Aug 05; published on the web 23 Aug 05)

\begin{abstract}
Pyridinium chlorides with long alkyl substituents were prepared, sometimes in quantitative yields, using a macroporous, strongly basic, anion exchange resin of the styrene-divinylbenzene type. This procedure opens the way to convert readily available and highly pure pyrylium salts with tailored amphiphilicity inducing substituents, into pyridinium perchlorates, and then by this optimized anion exchange procedure into the corresponding chlorides. Previous transfection studies using long chain pyridinium perchlorates have proven acute cell toxicity whereas the corresponding chlorides were benign and had good to high transfection efficiencies, superior to commercial nonviral vectors. All new compounds were fully characterized and can now be made available in large quantities.
\end{abstract}

Keywords: Pyridinium chloride, amphiphile, nonviral, gene delivary

\section{Introduction}

Recent in depth studies of cationic amphiphiles have demonstrated practical utility for the latter for delivery of DNA and RNA into cells. The groups of Jan Engberts and Dick Hoekestra describe the synthesis of pyridinium chlorides as amphiphiles by the quaternization of 4methylpyridine, in order to identify lead structures and to optimize the efficiency of these quaternary salts in transfection experiments. Some characteristics of amphiphile/DNA complex 
formation were also presented. ${ }^{1,2}$ Although their synthetic methods are non demanding and highyielding, the pyridinium polar head group in their constructs was minimally substituted. Sandy Balaban, to whom this work is dedicated, has used the 2,4,6-trimethylpyridinium scaffold for attaching various lipophilic chains via the well known conversion of pyrylium salts into pyridinium salts by reaction with primary amines. ${ }^{3}$ Constructs using glycerolamines, by esterification with fatty acids of the two glycerol hydroxyl groups, have provided 2,4,6trimethylpyridinium-substituted compounds, which were tested in vivo, ${ }^{4,5}$ and have allowed structure-activity correlations. ${ }^{6}$ Marc Ilieş and Sandy Balaban have also reviewed their work as well as recent developments in non-viral gene delivery. ${ }^{7}$ A very recent comprehensive study by Jean-Pierre Vigneron, Jean-Marie Lehn and Pierre Lehn and their coworkers summarizes the present status of cationic lipids in the field of non-viral gene therapies. ${ }^{8}$

Our group has been involved since 1991 in synthesizing amphiphilic pyridinium salts with the long chains attached directly to the pyridinium nucleus. This design could combine in a unique manner $(i)$ ionic pairing with the anionic nucleic acid strands, (ii) $\pi-\pi$ stacking interactions of the pyridinium cation, and (iii) hydrophobic packing between the long chains which in an aqueous environment leads to micellar aggregates. More than fifty new compounds were assessed and previous papers describe their preparation from either 2, 4, 6-trisubstituted or 2, 3, 4, 6-tetra-substituted pyrylium salts having either one, or two linear $\alpha / \gamma$-alkyl side chains. ${ }^{9-}$ 15 All these pyrylium salts were synthesized as perchlorates, which although hazardous compounds that could lead potentially to powerful explosions, when handled with care, allow an unprecedented and easy purification from the complex reaction mixtures. A comprehensive review on the available methods for the synthesis of pyrylium salts, including detailed experimental procedures involving different anions, has been recently published in a father-son co-authorship. ${ }^{16}$

Ammonium perchlorate, which has been widely used as a solid rocket propellant and missile fuel, is known to contaminate drinking water, groundwater or soil. The perchlorate anion is a powerful thyroid toxin that can affect the thyroid's ability to take up the essential nutrient iodide used to make thyroid hormones. Edwards reported earlier on substrate inhibition of active iodide secretion in saliva by nitrate and also by thiocyanate and perchlorate anions. ${ }^{17}$ The perchlorate anion has been primarily studied in human patients with Graves' disease. Graves' disease is an autoimmune disorder in which patients have antibodies to the TSH receptors in the thyroid. As a result, patients are hyperthyroid with thyroids that are actively pumping iodide and producing elevated levels of the thyroid hormones T3 and T4. ${ }^{18-20}$ All our cell culture assays involving pyridinium perchlorates proved an enhanced cytotoxicity and thus these compounds were abandoned for transfection studies. Thus, it was highly desirable to develop a facile, highyielding anion exchange method, chloride being among the most used anion. Unfortunately, the synthesis of pyrylium chlorides is non-practical leading to impure and usually hygroscopic oils. Pyridinium salts with long alkyl substituents are expected to have surfactant properties ${ }^{21,22}$ and are microbiologically active compounds. ${ }^{23}$ On the other hand, pyridinium chlorides have antibacterial activity $^{24}$ and cetylpyridinum chloride was useful for isolation of Mycobacterium 
tuberculosis from sputa. ${ }^{25}$ For $N$-octyl pyridinum chloride, practical uses as surfactant, ${ }^{26}$ disinfectant ${ }^{27}$ and industrial applications as cleaning agent, ${ }^{28}$ for modification of properties of ion exchange membranes $^{29}$ or water-dispersible agents were also described. ${ }^{30}$

Ion exchange processes can be very useful in organic chemistry and can be simply carried out on various solid supports in high yields. Some of the known industrial processes utilizing ion exchange materials are ${ }^{31}$ : (i) conversion of one salt to another, (ii) removal of ionic impurities from organic compounds, (iii) separation of both inorganic and organic ions by chromatography, (iv) catalysis. One example of converting a pyridinium perchlorate, which is not a pharmaceutically acceptable ingredient, to the corresponding chloride salt was reported. ${ }^{32}$

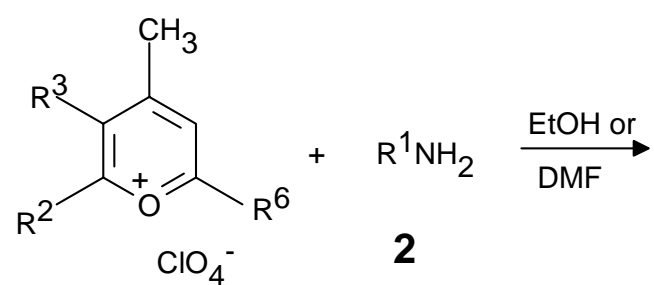

1

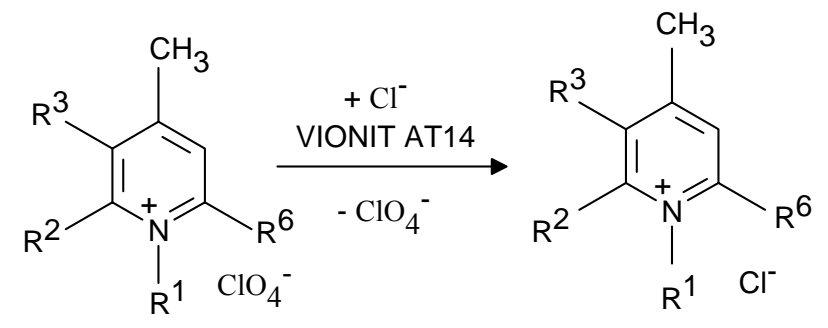

$3-10$

$3 \mathrm{Cl}-10 \mathrm{Cl}$

\begin{tabular}{ccccc}
\hline Compound & $\mathrm{R}^{1}$ & $\mathrm{R}^{2}$ & $\mathrm{R}^{3}$ & $\mathrm{R}^{6}$ \\
\hline $\mathbf{3}$ & $\mathrm{CH}_{3}$ & $\mathrm{C}_{11} \mathrm{H}_{23}$ & $\mathrm{CH}_{3}$ & $\mathrm{C}_{11} \mathrm{H}_{23}$ \\
$\mathbf{3 C l}$ & $\mathrm{CH}_{3}$ & $\mathrm{C}_{11} \mathrm{H}_{23}$ & $\mathrm{CH}_{3}$ & $\mathrm{C}_{11} \mathrm{H}_{23}$ \\
$\mathbf{4}$ & $\mathrm{CH}_{3}$ & $\mathrm{C}_{11} \mathrm{H}_{23}$ & $\mathrm{H}$ & $\mathrm{C}_{11} \mathrm{H}_{23}$ \\
$\mathbf{4 C l}$ & $\mathrm{CH}_{3}$ & $\mathrm{C}_{11} \mathrm{H}_{23}$ & $\mathrm{H}$ & $\mathrm{C}_{11} \mathrm{H}_{23}$ \\
$\mathbf{5}$ & $\mathrm{C}_{12} \mathrm{H}_{25}$ & $\mathrm{C}_{11} \mathrm{H}_{23}$ & $\mathrm{H}$ & $\mathrm{CH}_{3}$ \\
$\mathbf{5 C l}$ & $\mathrm{C}_{12} \mathrm{H}_{25}$ & $\mathrm{C}_{11} \mathrm{H}_{23}$ & $\mathrm{H}$ & $\mathrm{CH}_{3}$ \\
$\mathbf{6}$ & $\mathrm{C}_{12} \mathrm{H}_{25}$ & $\mathrm{C}_{11} \mathrm{H}_{23}$ & $\mathrm{CH}_{3}$ & $\mathrm{CH}_{3}$ \\
$\mathbf{6 C l}$ & $\mathrm{C}_{12} \mathrm{H}_{25}$ & $\mathrm{C}_{11} \mathrm{H}_{23}$ & $\mathrm{CH}_{3}$ & $\mathrm{CH}_{3}$ \\
$\mathbf{7}$ & $\mathrm{CH}_{3}$ & $\mathrm{C}_{15} \mathrm{H}_{31}$ & $\mathrm{H}$ & $\mathrm{C}_{15} \mathrm{H}_{31}$ \\
$\mathbf{7 C l}$ & $\mathrm{CH}_{3}$ & $\mathrm{C}_{15} \mathrm{H}_{31}$ & $\mathrm{H}$ & $\mathrm{C}_{15} \mathrm{H}_{31}$ \\
$\mathbf{8}$ & $\mathrm{CH}_{3}$ & $\mathrm{C}_{15} \mathrm{H}_{31}$ & $\mathrm{CH}_{3}$ & $\mathrm{C}_{15} \mathrm{H}_{31}$ \\
$\mathbf{8 C l}$ & $\mathrm{CH}_{3}$ & $\mathrm{C}_{15} \mathrm{H}_{31}$ & $\mathrm{CH}_{3}$ & $\mathrm{C}_{15} \mathrm{H}_{31}$ \\
$\mathbf{9}$ & $\mathrm{CH}_{3}$ & $\mathrm{C}_{17} \mathrm{H}_{35}$ & $\mathrm{H}$ & $\mathrm{C}_{17} \mathrm{H}_{35}$ \\
$\mathbf{9 C l}$ & $\mathrm{CH}_{3}$ & $\mathrm{C}_{17} \mathrm{H}_{35}$ & $\mathrm{H}$ & $\mathrm{C}_{17} \mathrm{H}_{35}$ \\
$\mathbf{1 0}$ & $\mathrm{CH}_{3}$ & $\mathrm{C}_{17} \mathrm{H}_{35}$ & $\mathrm{CH}_{3}$ & $\mathrm{C}_{17} \mathrm{H}_{35}$ \\
$\mathbf{1 0 C l}$ & $\mathrm{CH}_{3}$ & $\mathrm{C}_{17} \mathrm{H}_{35}$ & $\mathrm{CH}_{3}$ & $\mathrm{C}_{17} \mathrm{H}_{35}$ \\
\hline
\end{tabular}

Scheme 1. Synthesis of pyridinium chlorides from pyrylium perchlorates followed by anion exchange. 
The present paper describes the synthesis of 2,4,6-trisubstituted and 2,3,4,6-tetrasubstituted pyridinium chlorides having two various linear and long side chains in the 1,2- or 2,6-positions. An experimental procedure, spectral data and elemental analyses for all new compounds are presented. These novel chlorides are expected to be useful as efficient transfection vectors in nonviral gene therapy.

\section{Results and Discussion}

Conversion of pyrylium salts 1 into $N$-alkyl-pyridinium perchlorates (3-10) followed by anion exchange to $\mathrm{N}$-alkyl-pyridinium chlorides (3Cl-10Cl)

Pyridinium perchlorates 3-10 were prepared as previously described. ${ }^{9-15}$ Table 2 presents elemental analyses and melting points and the synthetic procedure for the anion exchange. Yields were $60-80 \%$. These compounds usually crystallize as colorless crystals $(N$-methylpyridinium perchlorates 3-4, $,{ }^{9,11}, \mathbf{7}$ and $\mathbf{9},{ }^{14} \mathbf{8}$ and $\mathbf{1 0},{ }^{15}$ ) or are waxy oils which crystallized in the refrigerator ( $N$-dodecylpyridinium perchlorates 5-6). All these compounds are soluble in fairly polar solvents such as lower alcohols, acetone, chloroform, methylene chloride, etc. $N$-Dodecylpyridinium perchlorates 5, 6 having two long alkyl side chains in positions 1- and 2- are highly soluble also in weakly polar solvents such as diethyl ether, a fact quite uncommon for organic salts. This was not the case for $N$-methylpyridinium perchlorates 3-4, 7-10 with 2, 6-dialkyl side chains as these could be precipitated from alcoholic solutions with diethyl ether. ${ }^{9-15}$

The conversion of pyridinum perchlorates 3-10 was easily performed by passing the perchlorate salts through the strongly basic ion exchange resin Vionit AT14 which was brought in the chloride form in order to afford the chloride salts $\mathbf{3 C l}-\mathbf{1 0 C l}$ in almost quantitative yields. All chlorides compounds are waxy oils but again the $N$-methyl pyridinium chlorides proved to have a higher crystallinity because although they were obtained as waxy oils, after prolonged standing they crystallized in the refrigerator exhibiting low melting points $\left(35-48^{\circ} \mathrm{C}\right)$ as detailed in Table 2. All the chlorides were fairly soluble in diethyl ether.

Two mixtures of solvents were useful for the anion exchange to pyridinium chlorides namely methanol: water and acetone: water. The influence of the solvent and water concentration on the yield in pyridinium chloride was studied in some detail for $\mathbf{4 C l}$ and $\mathbf{5 C l}$ and is presented in Table 3. In all cases the use of a methanol : water mixture gave less satisfactory results. It should be noted, however, that slow exchange, presumably via decyclization to the 1-amino-1,3-dien-5one 12, ${ }^{3}$ occurred when compounds were eluted with solvent mixtures containing methanol (Scheme 2). A mixture of $\mathrm{Cl}^{-} / \mathrm{ClO}_{4}{ }^{-}$pyridinium salts and ring-opened products 12-13 was obtained in these cases, showing that this system is inefficient, due not only to the incomplete anion exchange, but also due to an undesired ring opening. 
Table 2. The new compounds

\begin{tabular}{|c|c|c|c|c|c|c|c|}
\hline \multirow[t]{2}{*}{ Compound } & \multirow[t]{2}{*}{ Mol. Form. } & \multicolumn{2}{|c|}{ E.A. $(\%)$} & \multirow[t]{2}{*}{ Aspecta } & \multirow{2}{*}{$\begin{array}{l}\text { m.p. } \\
(\mathrm{oC})\end{array}$} & \multirow{2}{*}{$\begin{array}{l}\text { Synthesis } \\
\text { Solvent }\end{array}$} & \multirow{2}{*}{$\begin{array}{l}\text { Solvents } \\
\text { Ion Exchange } \\
\text { (vol:vol) }\end{array}$} \\
\hline & & Calcd. & Found & & & & \\
\hline 3 & $\mathrm{C}_{30} \mathrm{H}_{56} \mathrm{NClO}_{4}$ & $\begin{array}{l}\mathrm{N}: 2.64 \\
\mathrm{Cl}: 6.70\end{array}$ & $\begin{array}{l}\mathrm{N}: 2.70 \\
\mathrm{Cl}: 6.68\end{array}$ & $\mathrm{CC}$ & $\mathrm{CC}$ & $\mathrm{C}_{2} \mathrm{H}_{5} \mathrm{OH}$ & - \\
\hline $3 \mathrm{Cl}$ & $\mathrm{C}_{30} \mathrm{H}_{56} \mathrm{NCl}$ & $\begin{array}{l}\mathrm{N}: 3.01 \\
\mathrm{Cl}: 7.63\end{array}$ & $\begin{array}{l}\mathrm{N}: 3.04 \\
\mathrm{Cl}: 7.60\end{array}$ & WOCR & WOCR & - & $\begin{array}{c}\left(\mathrm{CH}_{3}\right)_{2} \mathrm{CO}: \mathrm{H}_{2} \mathrm{O}= \\
65: 5\end{array}$ \\
\hline 4 & $\mathrm{C}_{29} \mathrm{H}_{54} \mathrm{NClO}_{4}$ & $\begin{array}{l}\mathrm{N}: 2.71 \\
\mathrm{Cl}: 6.89\end{array}$ & $\begin{array}{l}\mathrm{N}: 2.68 \\
\mathrm{Cl}: 6.88\end{array}$ & $\mathrm{CC}$ & $\mathrm{CC}$ & $\mathrm{C}_{2} \mathrm{H}_{5} \mathrm{OH}$ & - \\
\hline $4 \mathrm{Cl}$ & $\mathrm{C}_{29} \mathrm{H}_{54} \mathrm{NCl}$ & $\begin{array}{l}\mathrm{N}: 3.10 \\
\mathrm{Cl}: 7.86\end{array}$ & $\begin{array}{l}\mathrm{N}: 3.09 \\
\mathrm{Cl}: 7.85\end{array}$ & WOCR & $41-42$ & - & $\begin{array}{c}\left(\mathrm{CH}_{3}\right)_{2} \mathrm{CO}: \mathrm{H}_{2} \mathrm{O}= \\
65: 5\end{array}$ \\
\hline 5 & $\mathrm{C}_{30} \mathrm{H}_{56} \mathrm{NClO}_{4}$ & $\begin{array}{l}\mathrm{N}: 2.64 \\
\mathrm{Cl}: 6.70\end{array}$ & $\begin{array}{l}\mathrm{N}: 2.68 \\
\mathrm{Cl}: 6.72\end{array}$ & WOCR & $34.5-35$ & $\mathrm{CH}_{2} \mathrm{Cl}_{2}$ & - \\
\hline $5 \mathrm{Cl}$ & $\mathrm{C}_{30} \mathrm{H}_{56} \mathrm{NCl}$ & $\begin{array}{l}\mathrm{N}: 3.01 \\
\mathrm{Cl}: 7.63\end{array}$ & $\begin{array}{l}\mathrm{N}: 3.03 \\
\mathrm{Cl}: 7.65\end{array}$ & Waxy oil & - & - & $\begin{array}{c}\left(\mathrm{CH}_{3}\right)_{2} \mathrm{CO}: \mathrm{H}_{2} \mathrm{O}= \\
50: 4\end{array}$ \\
\hline 6 & $\mathrm{C}_{41} \mathrm{H}_{78} \mathrm{NClO}_{4}$ & $\begin{array}{l}\mathrm{N}: 2.05 \\
\mathrm{Cl}: 5.19\end{array}$ & $\begin{array}{l}\mathrm{N}: 2.18 \\
\mathrm{Cl}: 5.20\end{array}$ & WOCR & $44-45$ & DMF & - \\
\hline $6 \mathrm{Cl}$ & $\mathrm{C}_{41} \mathrm{H}_{78} \mathrm{NCl}$ & $\begin{array}{l}\mathrm{N}: 2.26 \\
\mathrm{Cl}: 5.73\end{array}$ & $\begin{array}{l}\mathrm{N}: 2.28 \\
\mathrm{Cl}: 5.72\end{array}$ & Waxy oil & - & - & $\begin{array}{c}\left(\mathrm{CH}_{3}\right)_{2} \mathrm{CO}: \mathrm{H}_{2} \mathrm{O}= \\
50: 4\end{array}$ \\
\hline $7 \mathrm{Cl}$ & $\mathrm{C}_{37} \mathrm{H}_{70} \mathrm{NCl}$ & $\begin{array}{l}\mathrm{N}: 2.48 \\
\mathrm{Cl}: 6.30\end{array}$ & $\begin{array}{l}\mathrm{N}: 2.46 \\
\mathrm{Cl}: 6.29\end{array}$ & WOCR & $44-45$ & - & $\begin{array}{c}\left(\mathrm{CH}_{3}\right)_{2} \mathrm{CO}: \mathrm{H}_{2} \mathrm{O}= \\
60: 5\end{array}$ \\
\hline $8 \mathrm{Cl}$ & $\mathrm{C}_{38} \mathrm{H}_{72} \mathrm{NCl}$ & $\begin{array}{l}\mathrm{N}: 2.42 \\
\mathrm{Cl}: 6.15\end{array}$ & $\begin{array}{l}\mathrm{N}: 2.40 \\
\mathrm{Cl}: 6.14\end{array}$ & WOCR & $39-40$ & - & $\begin{array}{c}\left(\mathrm{CH}_{3}\right)_{2} \mathrm{CO}: \mathrm{H}_{2} \mathrm{O}= \\
65: 5\end{array}$ \\
\hline $9 \mathrm{Cl}$ & $\mathrm{C}_{41} \mathrm{H}_{78} \mathrm{NCl}$ & $\begin{array}{l}\mathrm{N}: 2.26 \\
\mathrm{Cl}: 5.70\end{array}$ & $\begin{array}{l}\mathrm{N}: 2.26 \\
\mathrm{Cl}: 5.71\end{array}$ & WOCR & $46-47.5$ & - & $\begin{array}{c}\left(\mathrm{CH}_{3}\right)_{2} \mathrm{CO}: \mathrm{H}_{2} \mathrm{O}= \\
60: 5\end{array}$ \\
\hline $10 \mathrm{Cl}$ & $\mathrm{C}_{42} \mathrm{H}_{80} \mathrm{NCl}$ & $\begin{array}{l}\mathrm{N}: 2.21 \\
\mathrm{Cl}: 5.60\end{array}$ & $\begin{array}{l}\mathrm{N}: 2.22 \\
\mathrm{Cl}: 5.61\end{array}$ & WOCR & $36-37$ & - & $\begin{array}{c}\left(\mathrm{CH}_{3}\right)_{2} \mathrm{CO}: \mathrm{H}_{2} \mathrm{O}= \\
65: 5\end{array}$ \\
\hline
\end{tabular}

${ }^{\text {a }} \mathrm{CC}$ stands for Colorless Crystals while WOCR stands for Waxy Oil which Crystallized in the Refrigerator $\left(4^{\circ} \mathrm{C}\right)$. 
Table 3. Conversion of $N$-alkylpyridinium perchlorates $\mathbf{4}$ and $\mathbf{5}$ into $\mathrm{N}$-alkylpyridinium chlorides $4 \mathrm{Cl}$ and $\mathbf{5 C l}{ }^{\mathrm{a}}$

\begin{tabular}{cccccc}
\hline Compd. & Solvent Mixture & Vol:Vol & Product & $\mathrm{ClO} / \mathrm{Cl} b$ & Yield (\%) \\
\hline $\mathbf{4}$ & $\mathrm{CH}_{3} \mathrm{OH}: \mathrm{H}_{2} \mathrm{O}$ & $65: 5$ & $\begin{array}{c}\text { mixture of } \mathbf{4}, \\
\mathbf{4} \mathbf{C l} \text { and } \mathbf{1 2 - 1 3}\end{array}$ & $3: 2$ & $45 \mathrm{~d}$ \\
$\mathbf{4}$ & $\left(\mathrm{CH}_{3}\right)_{2} \mathrm{CO}: \mathrm{H}_{2} \mathrm{O}$ & $65: 10$ & $\begin{array}{c}\text { mixture of } \mathbf{4} \text { and } \\
\mathbf{4 C l}\end{array}$ & $1: 2$ & $70 \mathrm{~d}$ \\
$\mathbf{4}$ & $\left(\mathrm{CH}_{3}\right)_{2} \mathrm{CO}: \mathrm{H}_{2} \mathrm{O}$ & $65: 5$ & $\mathbf{4 C l}$ & - & $99 \mathrm{c}$ \\
$\mathbf{5}$ & $\mathrm{CH}_{3} \mathrm{OH}: \mathrm{H}_{2} \mathrm{O}$ & $65: 5$ & $\begin{array}{c}\text { mixture of } \mathbf{5}, \\
\mathbf{5 C l} \text { and } \mathbf{1 2 - 1 3}\end{array}$ & $1: 1$ & $50 \mathrm{~d}$ \\
$\mathbf{5}$ & $\left(\mathrm{CH}_{3}\right)_{2} \mathrm{CO}: \mathrm{H}_{2} \mathrm{O}$ & $50: 10$ & $\begin{array}{c}\text { mixture of } \mathbf{5} \text { and } \\
\mathbf{5 C l}\end{array}$ & $1: 2$ & $78 \mathrm{~d}$ \\
$\mathbf{5}$ & $\left(\mathrm{CH}_{3}\right)_{2} \mathrm{CO}: \mathrm{H}_{2} \mathrm{O}$ & $50: 4$ & $\mathbf{5 C l}$ & - & $99 \mathrm{c}$ \\
\hline
\end{tabular}

(a) All reactions were performed at $25^{\circ} \mathrm{C}$ using Vionit AT14. (b) determined by ${ }^{1} \mathrm{H}-\mathrm{NMR}$ (400 $\mathrm{MHz}$ ) analysis. (c) analytically pure compound. (d) determined after preparative TLC purification.

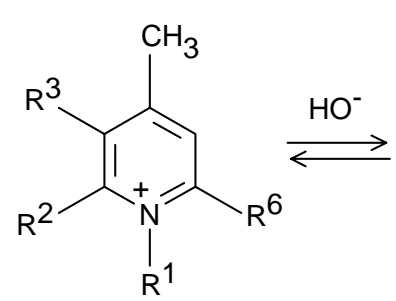

$3-10$

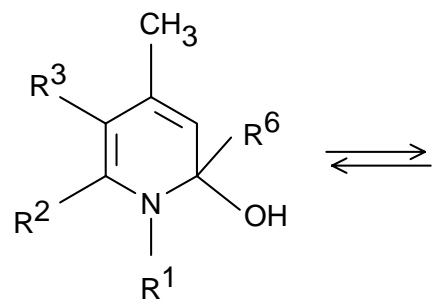

11

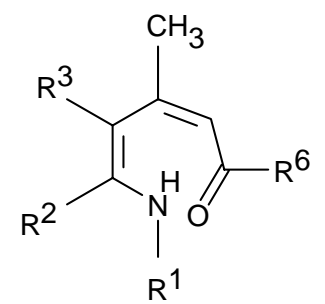

12

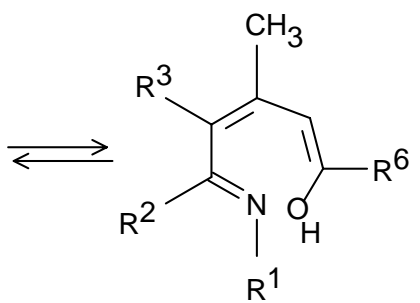

13

Scheme 2. Side reactions leading to a mixture of ring opened products.

High concentrations of water and high elution rates increased the anion exchange yields to pyridinium chlorides. The amount of water in the elution solvent mixtures is an important factor in determining the relative selectivity of the resin for $\mathrm{ClO}_{4} / \mathrm{Cl}$ ions. The use a mixture of acetone: water elution solvent in the second case gave the best results. The decrease in conversion into chlorides $\mathbf{4 C l}$ and $\mathbf{5 C l}$ with increasing water concentration is due to the differences between polarity of solvent and pyridinium solubility and also probably to the base catalyzed ring opening to the ketodiamine. We have not yet tried to suppress this side reaction by controlling the $\mathrm{pH}$ with various buffers.

The purification of the products sometimes met with difficulty so that after solvent evaporation, the reaction mixture had to be separated by thin layer chromatography (silica gel Merck type 60G, solvent diethyl ether: acetone $=9: 1$ ), when the pyridinium perchlorates remain adsorbed. For these cases, a mixture of solvents acetone : water 65:5 (for $\mathbf{4 C l}$ ) or 50:4 (for $\mathbf{5 C I}$ ) 
affords excellent separation results and the pyridinium chlorides thus obtained were analytically pure compounds. The purity of pyridinium chlorides was confirmed by ${ }^{1} \mathrm{H}-\mathrm{NMR}$, IR spectra and elemental analyses. It is interesting to note that the long chains on our compounds allow easy purification of organic salts by chromatography, which ensures highly pure compounds of GMP quality. It is not so common practice in preparative organic chemistry to perform chromatographic separations, which may include also reverse phase HPLC, on ionic compounds.

\section{NMR and IR spectra}

The ${ }^{1} \mathrm{H}$ - and ${ }^{13} \mathrm{C}$-NMR chemical shifts of pyridinium salts were in agreement with the previously reported NMR data on the 2,4,6-tri- or 2,3, 4, 6-tetrasubstitured homologs. ${ }^{9-15}$ The atom numbering for NMR assignments follows the one shown in Chart 1. Unambiguous assignments for 3Cl-10Cl were accomplished using two-dimensional correlation spectroscopy (COSY). Table 4 presents the proton chemical shifts and should allow an easy comparison of the data for the various compounds.

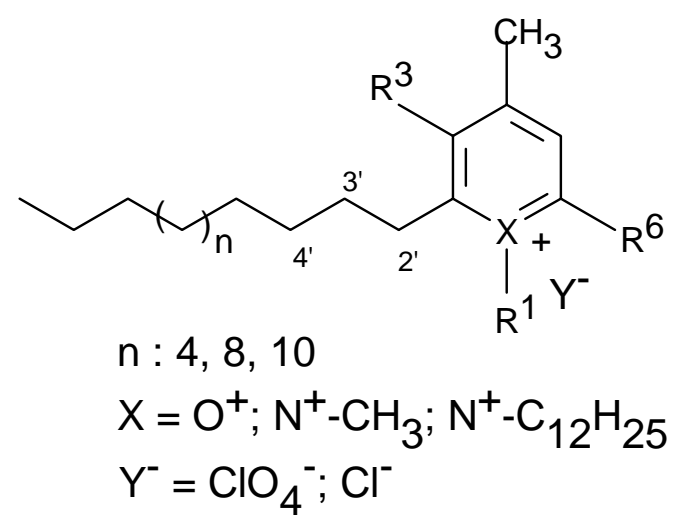

Chart 1. The compounds discussed in this work and their atom numbering scheme.

Most of the signals for $\mathbf{3 C l}-\mathbf{1 0 C l}$ were similar to those observed for the analogous perchlorates 3-10. A small systematic difference in chemical shifts values for the $\beta$-protons $(3 \mathrm{H} / 5 \mathrm{H})$ of the heterocyclic ring and the first alkyl side chain protons was observed (see Table 4). Comparison of the spectral data within 3Cl-10Cl and 3-10 indicates that the different anion pairing was responsible for differentiated ${ }^{1} \mathrm{H}-\mathrm{NMR}$ spectra and this could be used to quantify the mixtures with partially exchanged anions. The chloride anion leads to slightly more deshielded signals than the perchlorate.

The ${ }^{13} \mathrm{C}$-NMR spectra of pyridinium chlorides $\mathbf{3 C l}-\mathbf{1 0 C l}$ are summarized in table 5 where only those signals which could be safely assigned are listed. For all these compounds, similar spectra to those observed for the analogous perchlorates were obtained.

The only difference observed in the IR spectra was the absence of the sharp band at $625 \mathrm{~cm}^{-1}$ (when measured in $\mathrm{KBr}$ pellets) and of the broad and intense band at $1100 \mathrm{~cm}^{-1}$, both which correspond to the $\mathrm{ClO}_{4}$ anion. In Table 6 IR spectra for some typical compounds are presented. 
Table 4. Selected signal assignments for ${ }^{1} \mathrm{H}-\mathrm{NMR}$ spectra (400 MHz, recorded in $\mathrm{CDCl}_{3}$ ) of $\tilde{\mathbf{3}}-\mathbf{6}$ and $\mathbf{3 C l}-\mathbf{1 0 C l}$

\begin{tabular}{|c|c|c|c|c|c|c|c|c|c|c|c|c|}
\hline $\mathrm{Cpd}$ & $\begin{array}{l}3 \mathrm{C} \\
\mathrm{H}_{3}\end{array}$ & $\begin{array}{l}4 \mathrm{C} \\
\mathrm{H}_{3}\end{array}$ & $\begin{array}{l}6 \mathrm{C} \\
\mathrm{H}_{3}\end{array}$ & $3 \mathrm{H}$ & $5 \mathrm{H}$ & $2{ }_{2}{ }^{\prime} \mathrm{CH}_{2}$ & $\begin{array}{c}2{ }_{6}^{\prime} \mathrm{C} \\
\mathrm{H}_{2}\end{array}$ & $\begin{array}{c}3^{\prime} \mathrm{CH} \\
2\end{array}$ & $\begin{array}{c}4{ }^{\prime} \mathrm{CH} \\
2\end{array}$ & $\begin{array}{l}1^{\prime \prime} \mathrm{CH}_{2} \\
1^{\prime \prime} \mathrm{CH}_{3}\end{array}$ & $\begin{array}{l}2 " \mathrm{C} \\
\mathrm{H}_{2}\end{array}$ & $\begin{array}{l}3 " \mathrm{C} \\
\mathrm{H}_{2}\end{array}$ \\
\hline 3 & $\begin{array}{c}2.3 \\
7\end{array}$ & 2.49 & - & - & 7.38 & 3.09 & 3.02 & 1.84 & 1.39 & 4.17 & - & - \\
\hline $3 \mathrm{cl}$ & $\begin{array}{c}2.3 \\
8\end{array}$ & 2.50 & - & - & 7.41 & 3.30 & 3.23 & 1.88 & 1.39 & 4.38 & - & - \\
\hline 4 & - & 2.56 & - & 7.39 & - & 3.04 & - & 1.75 & 1.49 & 4.14 & - & - \\
\hline $4 \mathrm{cl}$ & - & 2.56 & - & 7.44 & - & 3.13 & - & 1.76 & 1.49 & 4.27 & - & - \\
\hline 5 & - & 2.54 & 2.85 & 7.45 & 7.55 & 2.98 & - & 1.77 & 1.47 & 4.28 & 1.77 & 1.47 \\
\hline $5 \mathrm{cl}$ & - & 2.57 & 3.02 & 7.49 & 7.67 & 3.07 & - & 1.78 & 1.49 & 4.58 & 1.78 & 1.49 \\
\hline 6 & $\begin{array}{c}2.3 \\
8\end{array}$ & 2.50 & - & - & 7.44 & 2.99 & 2.96 & 1.70 & 1.49 & 4.36 & 1.84 & 1.49 \\
\hline 6cl & $\begin{array}{c}2.4 \\
0\end{array}$ & 2.54 & - & - & 7.60 & 3.15 & 3.08 & 1.84 & 1.49 & 4.51 & 1.84 & 1.49 \\
\hline $7 \mathrm{cl}$ & - & 2.58 & - & 7.41 & - & 3.14 & - & 1.77 & 1.48 & 4.22 & - & - \\
\hline $8 \mathrm{cl}$ & $\begin{array}{c}2.3 \\
9\end{array}$ & 2.59 & - & - & 7.41 & 3.20 & 3.18 & 1.88 & 1.49 & 4.29 & - & - \\
\hline 9cl & - & 2.56 & - & 7.41 & - & 3.15 & - & 1.77 & 1.48 & 4.27 & - & - \\
\hline
\end{tabular}


Table 5. Selected signal assignments for ${ }^{13} \mathrm{C}-\mathrm{NMR}\left(100 \mathrm{MHz}\right.$, recorded in $\left.\mathrm{CDCl}_{3}\right)$ of $\mathbf{3 , 5}$ and $3 \mathrm{Cl}, 5 \mathrm{Cl}$

\begin{tabular}{ccccc}
\hline \multirow{2}{*}{ Carbons } & \multicolumn{2}{c}{$N$-methyl } & \multicolumn{2}{c}{$N$-dodecyl } \\
\cline { 2 - 5 } & 3 & $3 \mathrm{Cl}$ & 5 & $5 \mathrm{Cl}$ \\
\hline $\mathrm{C}-2$ & 155.43 & 155.58 & 154.20 & 154.42 \\
$\mathrm{C} 4$ & 156.63 & 156.75 & 157.78 & 157.48 \\
$\mathrm{C}-6$ & 156.22 & 156.42 & 157.34 & 157.42 \\
$\mathrm{C}-3$ & 126.84 & 126.88 & 129.04 & 128.95 \\
$\mathrm{C}-5$ & 133.97 & 133.29 & 127.28 & 126.96 \\
$6-\mathrm{CH}_{3}$ & - & - & 21.28 & 21.32 \\
$4-\mathrm{CH}_{3}$ & 21.51 & 21.10 & 21.68 & 21.70 \\
$3-\mathrm{CH}_{3}$ & 15.47 & 15.55 & - & - \\
$2{ }^{\prime}-\mathrm{CH}_{2}$ & 34.15 & 34.28 & 33.13 & 33.06 \\
$26^{\prime}-\mathrm{CH}_{2}$ & 34.27 & 34.39 & - & - \\
$3^{\prime}-\mathrm{CH}_{2}$ & 29.73 & 30.88 & 28.78 & 28.73 \\
$10^{\prime}-\mathrm{CH}_{2}$ & 31.87 & 31.97 & 31.91 & 31.72 \\
$11^{\prime}-\mathrm{CH}_{2}$ & 22.63 & 22.70 & 22.68 & 22.52 \\
$12^{\prime}-\mathrm{CH}_{3}$ & 14.06 & 14.15 & 14.11 & 14.08 \\
$1^{\prime \prime}-\mathrm{CH}_{2}$ & - & - & 51.97 & 52.18 \\
$2^{\prime \prime}-\mathrm{CH}_{2}$ & - & - & 28.78 & 28.92 \\
$3^{\prime \prime}-\mathrm{CH}_{2}$ & - & - & 26.70 & 26.53 \\
$\omega^{\prime \prime}-\mathrm{CH}_{2}$ & 39.69 & 39.72 & 14.09 & 13.98 \\
\hline
\end{tabular}

Table 6. The IR spectra of 5-6 and $5 \mathrm{Cl}-\mathbf{6 C l}$ in $\mathrm{CH}_{2} \mathrm{Cl}_{2}$

\begin{tabular}{cc}
\hline Compound & $v\left(\mathrm{~cm}^{-1}\right)$ \\
\hline $\mathbf{5}$ & $1100 \mathrm{~s}, 1465 \mathrm{~m}, 1635 \mathrm{~m}, 2855 \mathrm{~ms}, 2930 \mathrm{w}$ \\
$5 \mathrm{Cl}$ & $980 \mathrm{~m}, 1000 \mathrm{~s}, 1465 \mathrm{~m}, 1630 \mathrm{~m}, 2855 \mathrm{~m}, 2930 \mathrm{w}$ \\
$\mathbf{6}$ & $1100 \mathrm{~s}, 1480 \mathrm{~m}, 1550 \mathrm{~m}, 1620 \mathrm{~m}, 1680 \mathrm{~m}, 2855 \mathrm{mv}, 2930 \mathrm{w}$ \\
$6 \mathrm{Cl}$ & $980 \mathrm{~m}, 1000 \mathrm{~s}, 1480 \mathrm{~m}, 1550 \mathrm{~ms}, 1620 \mathrm{~m}, 1680 \mathrm{~m}, 2855 \mathrm{~ms}, 2930 \mathrm{w}$ \\
\hline
\end{tabular}

The IR spectra for $\mathbf{1 , 3 - 1 0}$, and $\mathbf{3 C l}-\mathbf{1 0 C l}$ were in full agreement with those of the 2,4,6-tri- or 2,3, 4, 6-tetrasubstitured homologues described earlier. ${ }^{34}$ 
Table 7. Selected signal assignments for ${ }^{1} \mathrm{H}-(400 \mathrm{MHz})$ and ${ }^{13} \mathrm{C}-(100 \mathrm{MHz})$-NMR spectra, recorded in $\mathrm{CDCl}_{3}$ of 11-13 derived from $\mathbf{5}$ and $\mathbf{1 0}$

\begin{tabular}{cccc}
\hline $\begin{array}{c}\text { Compd. } \\
\mathbf{1 1 - 1 3}\end{array}$ & $\mathbf{5 / H}$ & $\mathbf{1 0} / \mathrm{H}$ & $\mathbf{1 0} / \mathrm{C}$ \\
from & & & \\
\hline $3-\mathrm{H}$ & 4.71 & 4.48 & - \\
$5-\mathrm{H}$ & 5.54 & - & - \\
$2-\mathrm{C}$ & - & - & 159.26 \\
$3-\mathrm{C}$ & - & - & 113.31 \\
$4-\mathrm{C}$ & - & - & 158.84 \\
$5-\mathrm{C}$ & - & - & 116.15 \\
$6-\mathrm{C}$ & - & - & 212.64 \\
$1^{\prime \prime} \mathrm{CH}_{2 /}$ & 3.67 & 3.42 & 34.39 \\
$1^{\prime \prime} \mathrm{CH}_{3}$ & & & \\
$2^{\prime}{ }_{2} \mathrm{CH}_{2}$ & 2.90 & 2.88 & 31.98 \\
$2^{\prime}{ }_{6} \mathrm{CH}_{2}$ & & 2.78 & 30.99 \\
$10^{\prime} \mathrm{CH}_{2}$ & $1.5-1.22^{\mathrm{a}}$ & $1.32-1.40^{\mathrm{b}}$ & 29.75 \\
$3^{\prime} \mathrm{CH}_{2}$ & $1.7-1.8^{\mathrm{c}}$ & $1.6-1.8^{\mathrm{d}}$ & 29.45 \\
$11^{\prime} \mathrm{CH}_{2}$ & $1.5-1.22^{\mathrm{a}}$ & $1.32-1.40^{\mathrm{b}}$ & 25.71 \\
$4 \mathrm{CH}_{3}$ & 2.31 & 2.33 & 22.74 \\
$3 \mathrm{CH}_{3}$ & - & 2.17 & 15.52 \\
$6 \mathrm{CH}_{3}$ & 2.45 & - & - \\
$\omega^{\circ} \mathrm{CH}_{3}$ & 0.96 & 0.90 & 14.15 \\
$\mathrm{OH}$ & 8.13 & 8.39 & - \\
$\mathrm{NH}$ & 3.80 & 3.79 & - \\
\hline
\end{tabular}

${ }^{\mathrm{a}} \mathrm{m}$, with $4^{\prime}-11^{\prime}, 2^{\prime \prime}-11^{\prime \prime} \mathrm{CH}_{2}{ }^{\mathrm{b}} \mathrm{m}$, with $4^{\prime}-11^{\prime} \mathrm{CH}_{2} .{ }^{\mathrm{c}}$ t, with $3^{\prime \prime} \mathrm{CH}_{2} \cdot{ }^{\mathrm{d}} \mathrm{t}, 3_{2}{ }^{\prime \prime}$ and $3{ }_{6}{ }^{\prime \prime} \mathrm{CH}_{2}{ }^{\prime} \mathrm{m}$, with $4^{\prime}-$ $11^{\prime} \mathrm{CH}_{2}$.

IR and UV spectra for 11-13 derived from 5, recorded in a cyclohexane solution IR: $v\left(\mathrm{~cm}^{-1}\right), 1120 \mathrm{~m}, 1260 \mathrm{w}, 1465 \mathrm{w}, 1550 \mathrm{~m}, 1730 \mathrm{~m}, 2855 \mathrm{~m}, 2930 \mathrm{~m}, 3420 \mathrm{~m}$.

$\mathrm{UV}: \lambda_{\max }(\mathrm{nm}), 227,253,277$.

\section{Experimental Section}

General Procedures. The NMR spectra have been recorded on a Bruker Avance DRX 400 instrument, equipped with a $5 \mathrm{~mm}$ inverse detection multinuclear probe head and field gradients on the $\mathrm{z}$ axis, operating at $400 \mathrm{MHz}$ for ${ }^{1} \mathrm{H}$ and at $100 \mathrm{MHz}$ for ${ }^{13} \mathrm{C}$ nuclei. All spectra have been recorded in deuterated chloroform, and the chemical shifts have been reported as $\delta$ values 
referenced to TMS as internal standard. Infrared spectra were run on a Zeiss UR 20 instrument. Melting points were measured in open capillary tubes (for the low melting compounds) or on a hot-stage melting point apparatus which was equipped with a polarizer in order to check for nematic properties. All other reagents were obtained from commercial sources and purified by standard methods as necessary.

\section{Materials and Methods}

The synthesis of pyridinium salts with long alkyl substituents 3-10 via pyrylium salts $\mathbf{1}$ has been described in detail elsewhere. ${ }^{9-15}$ Briefly, these reactions were performed by refluxing of reactants in ethanol / dimethylformamide, or according to the method optimized by Katritzky, at room temperature in methylene chloride. ${ }^{33}$ Pyridinium chlorides were conveniently prepared by passing the perchlorate salts through a strongly basic ion exchange resin of the styrenedivinylbenzene type and afforded the chloride salt $\mathbf{3 C l}-\mathbf{1 0 C l}$ in yields higher than 99\%. Scheme 1 presents the synthesis of the new compounds which are described in this paper, while the atom numbering is shown in Chart 1.

All new compounds were fully characterized by ${ }^{1} \mathrm{H}$ - and ${ }^{13} \mathrm{C}-\mathrm{NMR}$ (at $400 \mathrm{MHz}$ for protons and at $100 \mathrm{MHz}$ for carbons), by IR spectra and by elemental analysis.

Conversion of $\mathbf{N}$-alkyl-pyridinium perchlorates 3-10 into $\mathbf{N}$-alkyl-pyridinium chlorides 3Cl10Cl. General Procedure. Vionit AT14 - chloride (0.3-1.25 mm, 1.5-2 g) was slurried with aqueous $\mathrm{HCl} 6 \%$ (deionized water use is recommended) and packed onto an usual chromatography column. The resin was washed with $6 \% \mathrm{HCl}$ until the effluent was clear (4-5 bed volumes), deionized water until the $\mathrm{pH}$ climbed to 7 (4-6 bed volumes), and finally with an acetone / water mixture (60:5-65:5 vol/vol or according to Table 2). The perchlorate salts (0.03$0.06 \mathrm{~g}, 0.12-0.14 \mathrm{mmol})$ dissolved in acetone / water (10:1) were loaded onto the column and eluted with acetone/water (60:5-65:5 vol/vol, or according to Table 2). The appropriate fractions were evaporated and the resulting solid further dried in a vacuum oven. Elemental analyses for the chloride salts were in agreement for successful ion exchange.

\section{Acknowledgements}

Thanks are expressed to Mrs. Marieta Plaveti for elemental analyses and to Mariana Maganu for IR spectra. The NMR spectra have been recorded in the National NMR Laboratory, co-founded and presently supported by Bruker, Spectroteam for Romania, Institute of Organic Chemistry and Oltchim SA. Dr. Filip Chiraleu is acknowledged for helpful discussions and routine NMR spectra. 


\section{References}

$\S \quad$ This is contribution no. 9 in the series "Pyrylium Salts with Long Alkyl Substituents". For some previous papers in this series see ref. 9-15.

1. Meekel, D. A. P.; Wagenaar, A.; Šmisterová,, J.; Kroez, J. E.; Haadsna, P.; Basgroof, B.; Stuart, M. C.; Brisson, A.; Ruiters, M. J. H.; Hoekestra, D.; Engberts, J. B. F. N. Eur. J. Org. Chem. 2000, 665.

2. Roosjen, A.; Šmisterová, J.; Driessen, C.; Anders, J. T.; Wagenaar, A.; Hoekstra D.; Hulst R.; Engberts J. B. F. N. Eur. J. Org. Chem. 2002, 1271.

3. Balaban, A. T.; Dinculescu, A.; Dorofeenko, G. N.; Fischer, G. W.; Koblik, A. V.; Mezheritskii, V. V.; Schroth, W. In Pyrylium Salts. Syntheses, Reactions and Physical Properties, Katritzky, A. R., Ed. Academic Press: New-York, Adv. Heterocyclic Chem., Suppl. Vol. 2, 1984.

4. Ilieş, M. A.; Seitz, W. A.; Căproiu, M. T.; Wentz, M.; Garfield, R. E.; Balaban, A. T. Eur. J. Org. Chem. 2003, 2645.

5. Ilieş M. A.; Johnson, B. H.; Makori, F.; Miller, A.; Seitz, W. A.; Thompson, E. B.; Balaban, A. T. Archives Biochem. Biophys. 2005, 435, 217.

6. Ilieş, M. A.; Seitz, M. A.; Ghivirigă, I.; Johnson, B. H.; Miller A.; Thompson, E. B.; Balaban, A. T. J. Med. Chem. 2004, 47, 3744.

7. Ilieş, M. A.; Seitz, W. A.; Balaban, A. T. Curr. Pharm. Design 2002, 8, 2441.

8. Martin, B.; Sainlos, M.; Abbsaoui, A.; Oudhiri, N.; Hauchécone, M.; Vigneron, J.-P.; Lehn, J.-M.; Lehn, P. Curr. Pharm. Design 2005, 11, 375.

9. Balaban, T. S.; Bogăţian, M. V.; Plăveti, M.; Bădescu, V.; Mihai, G. Rev Roum. Chim. 1991, $36,229$.

10. Bogățian, M. V.; Deleanu, C.; Mihai, G.; Balaban, T. S. Z. Naturforsch. 1992, 47b, 1011.

11. Bogățian, M. V.; Mihai, G.; Plăveți, M.; Chiraleu, F.; Deleanu, C.; Bădescu, V.; Balaban, T. S., Rev Roum. Chim. 1996, 41, 979.

12. Bogăţian, M. V.; Mihai, G.; Plăveți, M.; Chiraleu, F.; Maganu, M.; Bădescu, V.; Balaban, T. S. Rev. Roum.Chim. 1998, 43, 315.

13. Bogățian, M. V. Ph. D. Thesis, Roumanian Academy, Institute of Organic Chemistry "Costin D. Nenitzescu”, 1998.

14. Bogățian, M. V.; Câmpeanu, V.; Şerban, S.; Mihai, G.; Balaban, T. S. Rev. Roum. Chim. 2001, 46, 115.

15. Bogățian, M. V.; Deleanu,C.; Udrea, S.; Chiraleu, F.; Plăveți, M.; Danilă, M. G.; Bogățian, G.; Balaban, T. S. Rev. Roum.Chim. 2003, 48, 717.

16. Balaban, T. S.; Balaban, A. T. "Pyrylium Salts" in Science of Synthesis - Houben-Weyl, Methods of Molecular Transformations, Thomas, E. J., Ed.; Thieme: Stuttgart, 2003; Ch. 14.1, Vol. 14, pp 11-200.

17. Edwards, D. A. W. Lancet 1954, 6, 498. 
18. Connell, J. M. C. Postgrad. Med. J. 1981, 57, 516.

19. Fawcett, J. W.; Clark, C. W. Br. Med. J. 1961, 27, 1537.

20. Balaban, A. T.; Cravey, M.; Ghiviriga, I. Heterocyclic Comm. 1994, 1, 17.

21. Isogai, N.; Narita, T.; Chen, L.; Hirata, M.; Gong, J. P.; Osada, Y. Colloids and Surfaces A: Physicochemical and Engineering Aspects 1999, 147, 189.

22. Hodge, D. J. U.S. Provisional Pat. Appl. 60/4,717,388, 2003.

23. (a) Narita, T.; Gong, J. P.; Osada, Y. J. Phys. Chem. 1998, 102, 4566. (b) Li X.; Zhao G. Colloid. Surf. 1992, 64, 185. (c) Causi, S.; De Lisi, R.; Milito, S. J. Soln. Chem. 1991, 20, 1031. (d) Fisicaro, E.; Pelizzetti, E.; Barbieri, M.; Savarino, P.; Viscardi, G. Thermochim. Acta 1990, 168, 143.

24. (a) Ueoka, S.; Chiba, T. Patent JP 2,000,129,277, 2000; (b) Abe, T. Patent JP 11,193,201, 1999.

25. Kawaguchi, K.; Itayama, H.; Kawasaki, Y.; Shiratsukayama, Y. Patent JP 2,002,053,895, 2002.

26. Sata, T. Colloid. Polym. Sci. 1978, 256, 62.

27. Kawasaki, Y.; Kawaguchi, K.; Matsuoka, M. Patent JP 2,002,038,372, 2002.

28. Mannisto, P. T.; Ranta, T.; Leppaluoto, J. Acta Endocrin. 1979, 91, 271.

29. Imazato, S.; Imai, T.; Russell, R. R. B.; Torii, M.; Ebisu, S. J Biomed Mater Res. 1998, 39, 511.

30. Pardini, M.; Varaine, F.; Iona, E.; Arzumanian, E.; Checchi, F.; Oggioni, M. R.; Orefici, G.; Fattorini, L. J. Clinic. Microbiol. 2005, 43, 442.

31. (a) Khym, J. X. In: Analytical Ion Exchange Procedures in Chemistry and Biology, PrenticeHall, Inc., Englewood, Cliffs, New Jersey, 1974. (b) Dörfner K. In: Ion Exchangers, Properties and Applications, Ann Arbor Science Publishers, Inc., Michigan, 1972. (c) Walton, H. F.; Rocklin, R. D. In: Ion Exchange in Analytical Chemistry, CRC Press, 1990.

32. Guzzo, P. R. In: Albany Molecular Research, Inc., Technical Reports 1997, 1, 4.

33. Katritzky, A. R.; Lloyd, J. M.; Patel, R. C. J. Chem. Soc., Perkin Trans. 1982, I, 117.

34. Balaban A. T.; Mateescu G. D. Tetrahedron 1962, 18, 1083. 